\title{
KEDUDUKAN DAN KEKUATAN HUKUM MEMORANDUM OF UNDERSTANDING (MOU) SEBAGAI TAHAP PRAKONTRAK (KAJIAN DARI SISI HUKUM PERIKATAN)
}

\author{
Devi Setiyaningsih \\ E-mail: devisetiya162@gmail.com \\ Mahasiswa Fakultas Hukum Universitas Sebelas Maret Surakarta \\ Ambar Budhisulistyawati \\ E-mail: ambarbudhi@gmail.com \\ Dosen Fakultas Hukum Univesitas Sebelas Maret Surakarta
}

\begin{abstract}
This article aimed to find out the MoU regulation according to Indonesian Law and the binding power of $\mathrm{MoU}$ according to the law contract. This research employed juridical normative approach, emphasizing on literature to obtain secondary data from primary, secondary, and tertiary law materials. The results of the research that special arrangements regarding the $\mathrm{MoU}$ are not found in various laws and regulations in indonesia. The basis for the entry into force of the MoU in Indonesia is based on the principle of freedom of contract, as stipulated in Article 1338 of the Civil Code. In addition, it is also subject to the provisions concerning the contract in the Civil Code which basically adheres to an open system, which means that each person is free to enter into an agreement, both which has been regulated in the Law and which has not been regulated in the Law.
\end{abstract}

Keyword: Position; Binding force; Memorandum of Understanding; Contract Law

\begin{abstract}
Abstrak
Artikel ini ditulis dengan tujuan untuk mengetahui bagaimana pengaturan Memorandum of Understanding (MoU) menurut hukum di Indonesia serta kekuatan mengikat MoU menurut hukum perikatan. Penelitian ini menggunakan pendekatan yuridis normatif yaitu menitikberatkan pada sumber kepustakaan untuk memperoleh data sekunder dari bahan hukum primer, bahan hukum sekunder, dan bahan hukum tersier. Hasil penelitian menunjukkan bahwa pengaturan khusus mengenai MoU tidak ditemukan di dalam berbagai peraturan perundang-undangan di Indonesia. Adapun dasar berlakunya MoU di Indonesia adalah didasarkan pada asas kebebasan berkontrak, sebagaimana diatur dalam Pasal 1338 KUHPerdata. Selain itu juga tunduk pada ketentuan tentang perikatan yang ada dalam KUH Perdata yang pada dasarnya menganut sistem terbuka, yaitu berarti setiap orang bebas mengadakan perjanjian, baik yang telah diatur dalam Undang-Undang maupun yang belum diatur dalam Undang-Undang.
\end{abstract}

Kata Kunci: Kedudukan; Kekuatan Mengikat; Memorandum of Understanding; Hukum Perikatan

\section{A. Pendahuluan}

Seiring dengan perkembangan zaman, perkembangan di berbagai aspek kehidupan juga ikut berkembang. Hal ini merupakan pertanda baik bagi Indonesia, jika dalam perkembangan di berbagai aspek kehidupan tersebut diiringi dengan tingkat hukum yang ketat dan meningkat, serta terwujud adanya kepastian hukum. Sebagai contohnya, ketika menjalin kerja sama hendaknya diawali dengan membuat suatu pernyataan atau perjanjian yang sah antara satu pihak dengan pihak lainnya. Dengan demikian, perjanjian tersebut akan berlaku sebagai undang-undang bagi pihak-pihak dalam perjanjian tersebut. Kitab Undang-Undang Hukum Perdata (selanjutnya disebut KUH Perdata) dalam Pasal 1313, yang menyatakan bahwa perjanjian adalah "suatu perbuatan dengan mana satu orang atau lebih mengikatkan dirinya terhadap satu orang lain atau lebih.".

Pada dasarnya suatu kontrak atau perjanjian berawal dari suatu perbedaan kepentingan di antara para pihak. Sehingga perumusan hubungan kontraktual tersebut pada umumnya selalu 
diawali dengan proses negosiasi diantara para pihak. Setelah ada kesepahaman atau kesepakatan atas kehendak untuk mengadakan kontrak tersebut, maka para pihak biasanya akan mengadakan suatu proses prakontraktual, salah satunya dengan pembuatan nota kesepahaman atau sering disebut dengan istilah "Memorandum of Understanding" (selanjutnya disebut MoU).

MoU atau disebut juga pra-kontrak, merupakan suatu perbuatan hukum dari salah satu pihak (subjek hukum) untuk menyatakan maksudnya kepada pihak lain akan sesuatu yang ditawarkan atau dimilikinya. Dengan kata lain MoU merupakan perjanjian pendahuluan yang mengatur dan memberikan kesempatan kepada para pihak untuk melakukan studi kelayakan terlebih dahulu sebelum membuat perjanjian yang lebih terperinci dan mengikat pada nantinya. Istilah MoU memuat keinginan masing-masing pihak sekaligus adanya tenggang waktu pencapaian kesepakatan untuk terjadinya kontrak (Huala Adolf, 2008: 29). MoU oleh para ahli disebut dengan 'Nota Kesepakatan', 'Nota Kesepahaman' atau 'Kontrak Awal'.

MoU sebagai persetujuan pendahuluan untuk membuat kontrak sebenarnya tidak dikenal dalam hukum konvensional di Indonesia, terutama dalam hukum kontrak di Indonesia. Tetapi dewasa ini sering dipraktikkan dengan mengadopsi apa yang dipraktikkan secara internasional (Revyza J. Dien, 2016: 95). Banyak hal yang melatarbelakangi dibuatnya MoU, salah satunya adalah karena prospek bisnis atau usaha dirasa belum jelas benar dan dengan negosiasi yang rumit dan belum ada jalan keluarnya. Sehingga dari pada tanpa ikatan apapun dibuatlah MoU.

Di dalam peraturan perundang-undangan Indonesia, tidak ada ketentuan yang secara khusus mengatur tentang MoU. Dalam KUH Perdata tidak terdapat satu ketentuan yang mengatur secara khusus tentang ketentuan-ketentuan 'kontrak awal' atau 'pra-kontrak' atau 'nota kesepahaman' atau 'nota kesepakatan'. Dalam Pasal 1320 KUH Perdata yang mengatur syarat umum sahnya suatu perjanjian di Indonesia tidak diatur mengenai proses sebelum terjadinya kontrak atau 'prakontrak' atau 'kontrak awal'. KUH Perdata sendiri juga tidak membuat norma hukum (Pasal) yang melarang para pihak yang akan membuat kontrak untuk melakukan/membuat MoU terlebih dahulu.Tidak diaturnya MoU ini dalam hukum kita, maka dalam praktiknya banyak menimbulkan kesimpangsiuran, misalnya; apakah MoU sesuai dengan peraturan hukum positif di Indonesia, atau apakah MoU bisa dikategorikan setingkat dengan Perjanjian yang diatur dalam KUHPerdata?.

Berdasarkan uraian di atas, selanjutnya akan di bahas mengenai kedudukan dan kekuatan hukum Memorandum of Understanding ( $\mathrm{MoU}$ ) sebagai tahap prakontrak dikaji dari sisi hukum perikatan.

\section{B. Metode Penelitian}

Jenis penelitian yang digunakan dalam penelitian ini adalah penelitian hukum normatif. Menurut Peter Mahmud Marzuki, segala penelitian yang berkaitan dengan hukum (legal reseach atau rechtsonderzoek) adalah selalu normatif (Peter Mahmud Marzuki, 2014: 56). Penelitian hukum normatif memiliki pengertian yang serupa dengan penelitian hukum doktrinal (doctrinal research), yaitu penelitian berdasarkan bahan-bahan hukum (library based) yang fokusnya pada membaca dan mempelajari bahan-bahan hukum primer dan sekunder. Penelitian ini dikategorikan sebagai penelitian yang bersifat preskriptif dan teknis atau terapan yaitu ilmu hukum yang mempelajari tujuan hukum, nilai-nilai keadilan, validitas aturan hukum, konsep-konsep hukum, dan normanorma hukum. Sebagai ilmu terapan, ilmu hukum menetapkan standar prosedur, ketentuanketentuan, rambu-rambu dalam melaksanakan aturan hukum (Peter Mahmud Marzuki, 2014: 22). Penelitian ini bersifat preskriptif karena berusaha menjawab isu hukum yang diangkat dengan argumentasi, teori, atau konsep baru sebagai preskripsi dalam menyelesaikan permasalahan yang dihadapi (Peter Mahmud Marzuki, 2014: 32). Penelitian preskriptif memiliki arti bahwa penelitian ini mengemukakan apa yang seyogyanya atau seharusnya (Peter Mahmud Marzuki, 2014: 41).

Dalam penelitian hukum ini memerlukan sumber-sumber bahan hukum yang digunakan untuk memecahkan isu hukum. Sumber-sumber hukum penelitian dapat dibedakan menjadi dua yaitu berupa bahan hukum primer dan bahan hukum sekunder (Peter Mahmud Marzuki, 2014: 181). 
Bahan hukum primer yang digunakan dalam penelitian hukum ini antara lain Kitab Undang-Undang Hukum Perdata. Serta bahan hukum sekunder yang digunakan buku-buku hukum, jurnal-jurnal hukum dan penelitian hukum yang relevan. Teknik pengumpulan bahan hukum yang digunakan penulis dalam penelitian ini adalah teknik studi kepustakaan (literature research) atau studi dokumen. Teknik analisis bahan hukum yang penulis gunakan dalam penelitian ini adalah dengan metode silogisme yang menggunakan pola pikir deduktif. Penggunaan metode deduksi ini berpangkal dari pengajuan premis mayor kemudian diajukan premis minor yang kemudian dari kedua premis tersebut ditarik kesimpulan atau conclusion. Di dalam logika silogistik untuk penalaran hukum yang merupakan premis mayor adalah aturan hukum, sedangkan premis minornya adalah fakta hukum (Peter Mahmud Marzuki, 2014: 89).

\section{Hasil Penelitian dan Pembahasan}

\section{Pengaturan Memorandum of Understanding (MoU) menurut Hukum di Indonesia}

Secara gramatikal Memorandum of Understanding (selanjutnya disebut MoU) diartikan sebagai nota kesepahaman. Dapat dirumuskan pengertian MoU adalah dasar penyusunan kontrak pada masa datang yang didasarkan pada hasil pemufakatan para pihak, baik secara tertulis maupun lisan (H. Salim HS, dkk, 2011: 46). Secara teori MoU bukanlah merupakan suatu kontrak karena memang masih merupakan kegiatan prakontrak (Munir Fuady, 2001: 38). Ada tiga tahap dalam membuat perjanjian, menurut teori baru, yaitu:

1. Tahap pracontractual, yaitu adanya penawaran dan penerimaan;

2. Tahap contractual, yaitu adanya persesuaian pernyataan kehendak antara para pihak:

3. Tahap postcontractual, yaitu pelaksanaan perjanjian (H. Salim HS, 2017: 26).

MoU sebenarnya tidak dikenal dalam hukum konvensional di Indonesia, terutama dalam hukum kontrak di Indonesia. Di dalam peraturan perundang-undangan Indonesia, tidak ada ketentuan yang secara khusus mengatur tentang MoU.

Adapun dasar berlakunya MoU di Indonesia adalah didasarkan pada asas kebebasan berkontrak, sebagaimana diatur dalam Pasal 1338 KUHPerdata, yang berbunyi:

(1). "Semua persetujuan yang dibuat sesuai dengan undang-undang, berlaku sebagai undangundang bagi mereka yang membuatnya.

(2). Persetujuan itu tidak dapat ditarik kembali selain dengan kesepakatan kedua belah pihak, atau karena alasan-alasan yang ditentukan oleh undang-undang.

(3). Persetujuan harus dilaksanakan dengan itikad baik".

Selain asas kebebasan berkontrak, salah satu asas yang menjadi dasar berlakunya Memorandum of Understanding (MoU) adalah asas kebiasaan. Asas kebiasaan maksudnya adalah suatu perjanjian tidak hanya mengikat untuk apa yang secara tegas diatur, akan tetapi juga hal-hal yang menurut kebiasaan lazim diikuti.

Istilah MoU oleh para ahli disebut dengan 'Nota Kesepahaman' atau 'Kontrak Awal'. Pada dasarnya suatu kotrak berawal dari suatu perbedaan atau ketidaksamaan kepentingan di antara para pihak. Sehingga perumusan hubungan kotraktual tersebut pada umumnya selalu diawali dengan proses negosiasi di antara para pihak. Setelah ada kesepahaman atau kesepakatan atas kehendak untuk mengadakan kontrak maka para pihak biasanya akan membuat MoU yang memuat keinginan masing-masing pihak sekaligus adanya tenggang waktu pencapaian kesepakatan untuk terjadinya kontrak (Fuad Lutfi, 2017: 181).

Secara internasional yang menjadi dasar hukum adanya Memorandum of Understanding (selanjutnya disebut MoU) adalah UU No. 24 Tahun 2000 tentang Perjanjian Internasional. Menurut Pasal 1 huruf a Undang-Undang Nomor 24 Tahun 2000, pengertian perjanjian internasional yaitu: "Perjanjian dalam bentuk dan nama tertentu, yang diatur dalam hukum internasional yang dibuat secara tertulis serta menimbulkan hak dan kewajiban di bidang 
hukum publik. Selanjutnya dalam penjelasan Undang-Undang Nomor 24 Tahun 2000 tentang Perjanjian Internasional disebutkan bahwa: "Perjanjian internasional yang dimaksud dalam undang-undang ini adalah setiap perjanjian di bidang hukum publik, diatur oleh hukum internasional, dan dibuat oleh pemerintah dengan negara, organisasi internasional, atau subjek hukum internasional lain."

Dilihat dari pengertian dan penjelasan umum Undang-Undang Nomor 24 Tahun 2000 tentang Perjanjian Internasional, maka perjanjian internasional dalam praktiknya dapat disamakan antara lain dengan:

1. Treaty (Perjanjian);

2. Convention (Konvensi/Kebiasaan Internasional);

3. Memorandum of Understanding (MoU) atau Nota Kesepahaman (H. Salim HS, dkk, 2011: 48)

Maka dapat disimpulkan bahwa MoU yang dibuat antara negara yang satu dengan negara yang lain termasuk dalam kategori perjanjian internasional.

Sampai saat ini hukum positif Indonesia belum mengatur secara khusus tentang berlakunya MoU. Namun mengingat bahwa MoU merupakan suatu perjanjian pendahuluan, maka pengaturannya tunduk pada ketentuan tentang perikatan yang ada dalam KUH Perdata yang pada dasarnya menganut sistem terbuka. Sistem terbuka berarti setiap orang bebas mengadakan perjanjian, baik yang telah diatur dalam Undang-Undang maupun yang belum diatur dalam Undang-Undang (Revyza J. Dien, 2016: 97).

Landasan hukum yang digunakan dalam praktik pembuatan dan pelaksanaan MoU di Indonesia didasarkan pada asas kebebasan berkontrak dalam Pasal $1338 \mathrm{KUH}$ Perdata. Asas kebebasan berkontrak yang diatur dalam Pasal 1338 ayat (1) KUHPerdata yang berbunyi: Semua persetujuan yang dibuat sesuai dengan undang-undang berlaku sebagai undangundang bagi mereka yang membuatnya, menjadi dasar untuk membuat MoU, mengadakan perjanjian pendahuluan dengan pihak manapun, menentukan isi MoU, pelaksanaan MoU, persyaratan MoU dan menentukan bentuk MoU yaitu secara tertulis.

\section{Kekuatan Mengikat Memorandum of Understanding (MoU) Ditinjau dari Sisi Hukum Perikatan}

MoU merupakan pernyataan persetujuan secara tidak langsung terhadap hubungannya dengan persetujuan lain, baik secara lisan maupun secara tertulis. Hal tersebut juga menunjukkan bahwa MoU termasuk perikatan karena berdasarkan Pasal $1233 \mathrm{KUH}$ Perdata tiap-tiap perikatan dilahirkan baik karena persetujuan. Selain itu dalam MoU melibatkan dua orang atau lebih seperti hanya para pihak dalam perikatan yang terdiri dari pihak yang berkewajiban pada satu sisi, dan pihak yang berhak atas pemenuhan kewajiban tersebut pada sisi lain.

Jika kita perhatikan dengan seksama rumusan yang diberikan dalam Pasal 1234 KUHPerdata, dimana menyatakan bahwa "Tiap-tiap perikatan adalah untuk memberikan sesuatu, untuk berbuat sesuatu, atau untuk tidak berbuat sesuatu", maka dapat dilihat bahwa Kitab Undang-Undang Hukum Perdata sangat menekankan pada kewajiban pemenuhan perikatan, yang dikelompokan menjadi 3 macam, yaitu dalam bentuk kewajiban untuk memberikan sesuatu, melakukan sesuatu dan atau untuk tidak melakukan sesuatu (Kartini Muljadi dan Gunawan Widjaja, 2004: 19).

Suatu MoU yang dibuat secara sah mempunyai ikatan hukum yang penuh sesuai dengan asas Pacta Sunt Servanda (janji itu mengikat para pihak) (Gerry Lintang, 2015: 143). Dengan demikian maka berlakunya MoU dapat disamakan dengan sebuah undang-undang yang mempunyai kekuatan mengikat dan memaksa, tetapi hanya menyangkut dan sebatas pada hal-hal yang pokok yang terdapat dalam MoU. 
Terdapat dua pandangan yang membahas tentang kekuatan mengikat dari MoU, yaitu (Munir Fuady, 2002: 93-94):

a) Memorandum of Understanding (MoU) sebagai suatu Gentlement agreement

Pandangan pertama berpendapat bahwa Memorandum of Understanding (selanjutnya disebut MoU) hanyalah merupakan suatu gentlement agreement. Berarti bahwa MoU tidak sama dengan perjanjian biasa, walaupun MoU dibuat bentuk yang paling kuat seperti dengan akta notaris sekalipun. Selain itu, MoUmengikat hanya sebatas ikatan moral belaka, dalam arti tidak mengikat secara hukum. Sebagai ikatan moral, jika ada pihak yang melakukan pengingkaran terhadap MoU maka dianggap tidak bermoral dan reputasinya akan jatuh di kalangan bisnis.

b) Memorandum of Understanding (MoU)sebagai suatu Agreement is agreement

Pandangan kedua berpendapat bahwa sekali suatu perjanjian dibuat, apapun bentuknya, lisan maupun tertulis, pendek maupun panjang, lengkap ataupun hanya mengatur hal-hal yang bersifat pokok, tetap saja merupakan perjanjian dan karenanya mempunyai kekuatan mengikat seperti layaknya suatu perjanjian, sehingga seluruh ketentuan pasal-pasal tentang hukum perjanjian telah bisa diterapkan kepadanya. Lebih formalnya yaitu kalau suatu perjanjian hanya mengatur hal-hal yang bersifat pokok saja, maka mengikatnya hanya terhadap hal-hal pokok tersebut. Atau jika suatu perjanjian hanya berlaku untuk suatu jangka waktu tertentu, maka mengikatnyapun hanya untuk jangka waktu tertentu tersebut. Para pihak tidak dapat dipaksakan untuk membuat perjanjian lebih rinci sebagai tindak lanjut dari MoU. Selama jangka waktu perjanjian itu masih berlangsung, para pihak tidak dapat membuat perjanjian yang sama dengan pihak lain.

Landasan lain dari MoU sebagai agreement is agreement adalah teori promissory astopel. Teori tersebut mengajarkan bahwa yang dianggap ada kesesuaian kehendak antara para pihak jika pihak lawan telah melakukan sesuatu sebagai akibat tindakan-tindakan pihak lainnya dianggap merupakan tawaran untuk ikatan suatu kontrak (Magnis Florencia Butar- Butar, dkk. 2017).

Di Negara-negara maju yang menganut common law system seperti Inggris dan Amerika Serikat, berdasarkan doktrin promissory estoppels, janji-janji pada tahap prakontrak bisa dituntut ganti kerugian apabila ada pihak yang merasa dirugikan. Doktrin promissory estoppels ini adalah suatu doktrin hukum yang mencegah seseorang pemberi janji (promissor) untuk menarik kembali janjinya, dalam hal pihak yang menerima janji (promise) karena kepercayaannya terhadap janji tersebut telah melakukan sesuatu perbuatan atau tidak berbuat sesuatu, sehingga penerima janji akan menderita kerugian. Maka pada tahap negosiasi atau prakontrak dapat dituntut ganti kerugian. Hal ini untuk melindungi pihak penerima janji yang telah melakukan atau tidak melakukan sesuatu perbuatan, sehingga akan mengalami kerugian apabila pihak pemberi janji menarik janjinya (I Gede Prim Hadi Susetya, dkk. 2018).

Suatu MoU yang dibuat secara sah mempunyai ikatan hukum yang penuh sesuai dengan asas Pacta Sunt Servanda (janji itu mengikat para pihak). Dengan demikian maka berlakunya MoU dapat disamakan dengan sebuah undang-undang yang mempunyai kekuatan mengikat dan memaksa, tetapi hanya menyangkut dan sebatas pada hal-hal yang pokok yang terdapat dalam MoU. Dapat disimpulkan juga bahwa kekuatan mengikat antara MoU dengan perjanjian adalah sama, karena MoU dibuat berdasarkan kesepakatan para pihak yang akan mengikatkan dirinya pada isi dari MoU, dan dibuat dengan memenuhi syarat sahnya suatu perjanjian sebagaimana diatur dalam Pasal $1320 \mathrm{KUH}$ Perdata, serta kekuatan hukumnya akan mengikat pihak-pihak yang melanggar dengan ketentuan wanprestasi seperti diatur dalam KUH Perdata. 


\section{Simpulan}

1. Sampai saat ini hukum positif Indonesia belum mengatur secara khusus tentang berlakunya MoU. Namun mengingat bahwa MoU merupakan suatu perjanjian pendahuluan, maka pengaturannya tunduk pada ketentuan tentang perikatan yang ada dalam KUH Perdata yang pada dasarnya menganut sistem terbuka. Sistem terbuka berarti setiap orang bebas mengadakan perjanjian, baik yang telah diatur dalam Undang-Undang maupun yang belum diatur dalam Undang-Undang. Landasan hukum yang digunakan dalam praktik pembuatan dan pelaksanaan MoU di Indonesia didasarkan pada asas kebebasan berkontrak dalam Pasal 1338 KUH Perdata.

2. MoU merupakan pernyataan persetujuan secara tidak langsung terhadap hubungannya dengan persetujuan lain, baik secara lisan maupun secara tertulis. Hal tersebut juga menunjukkan bahwa MoU termasuk perikatan karena berdasarkan Pasal 1233 KUH Perdata tiap-tiap perikatan dilahirkan baik karena persetujuan. Selain itu dalam MoU melibatkan dua orang atau lebih seperti hanya para pihak dalam perikatan yang terdiri dari pihak yang berkewajiban pada satu sisi, dan pihak yang berhak atas pemenuhan kewajiban tersebut pada sisi lain. Dan dapat disimpulkan MoU tidak bersifat kontrak dan menganut teori Getelment Agreement.Untuk MoU yang sifatnya bukan merupakan suatu kontrak, hanya mempunyai sanksi moral.

\section{E. Saran}

Para pihak pelaksana bisnis di Indonesia harus lebih mengenal dan memahami tentang MoU, agar bisnis di Indonesia lebih baik sebab pebisnis asing sudah sering menerapkan MoU. Selain itu pemahaman mengenai kedudukan dan kekuatan hukum MoU akan menghindarkan kesalahpahaman tentang MoU itu sendiri mengenai fungsinya, ciri, jenis, dan sanksi yang didapat bila terjadi wanprestasi dalam MoU tersebut. Sebelum menyetujui MoU, diperlukan kejelian dan ketelitian terkait substansi dan sanksinya untuk menentukan kedudukan MoU tersebut di mata hukum.

\section{F Daftar Pustaka}

\section{Buku}

H. Salim HS, Abdullah, dan Wiwiek Wahyuningsih. 2011. Perancangan Kontrak \& Memorandum of Understanding (MoU). Ed. 1. Cet. 5. Jakarta: Sinar Grafika

H. Salim HS. 2017. Hukum Kontrak: Teori dan Teknik Penyusunan Kontrak. Cet. 12. Jakarta: Sinar Grafika

Huala Adolf. 2008. Dasar-dasar Hukum Kontrak Internasional. Ed.Revisi. Bandung: Refika Aditama

Kartini Muljadi dan Gunawan Widjaja. 2004. Perikatan Pada Umumnya. Ed. 1. Cet. 2. Jakarta: PT Raja Grafindo Persada

Munir Fuady. 2001. Hukum Kontrak (Dari Sudut Pndang Hukum Bisnis). Bandung: PT Citra Aditya. 2002. Hukum Bisnis dalam Teori dan Praktik. Buku Keempat. Bandung: Citra Aditya Bakti

Peter Mahmud Marzuki. 2014. Penelitian Hukum. Jakarta: Kencana Prenada Media Group

\section{Jurnal}

Fuad Lutfi. 2017. "Implemenetasi Yuridis tentang Kedudukan Memorandum of Understanding (MoU) dalam Sistem Hukum Perjanjian Indonesia". Jurnal Syariah: Jurnal IImu Hukum dan Pemikiran Vol. 17 No. 2 Desember 2017. Banjarmasin: Fakultas Syari'ah dan Ekonomi Islam UIN Antasari.

Gerry Lintang. 2015. "Kekuatan Hukum Memorandum of Understanding Ditinjau dari Segi Hukum Perikatan". Jurnal Lex Administratum Vol. III No. 8 Oktober 2015. Manado: Fakultas Hukum Universitas Sam Ratulangi. 
I Gede Prim Hadi Susetya, dkk. 2018. "Adaptasi Doktrin Promissory Estoppel dalam Penyelesaian Ganti Rugi pada Tahap Pra-Kontrak pada Hukum Kontrak di Indonesia". Jurnal IImiah Prodi Magister Kenotariatan, 2017-2018. Bali: Prodi Magister Kenotariatan Fakultas Hukum Universitas Udayana.

Magnis Florencia Butar- Butar, dkk. 2017. "Penerapan Doktrin Promissory Estoppel dalam Pemenuhan Prestasi Sebagai Akibat Adanya Perjanjian Anjak Piutang di Indonesia". Diponegoro Law Journal Volume 6. Nomor 2. Tahun 2017. Semarang: Fakultas Hukum Universitas Diponegoro.

Revyza J. Dien. 2016. "Kedudukan dan Kekuatan Hukum Memorandum of Understanding Menurut Hukum Perdata". Jurnal Lex Privatum Vol. IV No. 4 April 2016. Manado: Fakultas Hukum Universitas Sam Ratulangi.. 